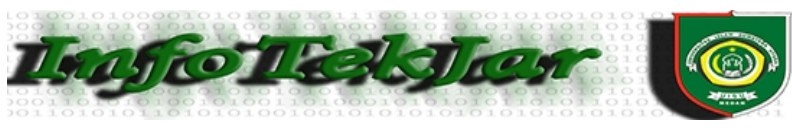

\title{
SISTEM PENDETEKSIAN KEMIRIPAN JUDUL SKRIPSI MENGGUNAKAN ALGORITMA WINNOWING
}

\author{
Nurdin $^{1}$, Amin Munthoha ${ }^{1}$ \\ ${ }^{1}$ Prodi Teknik Informatika Fakultas Teknik Universitas Malikussaleh \\ Jalan Cot Teungku Nie Reuleut Kecamatan Muara Batu Aceh Utara \\ Email:nurdin@unimal.ac.id
}

\begin{abstract}
Abstrak- Proses pengelolaan judul skripsi yang telah ada dan pendistribusian informasi kepada mahasiswa serta penentuan diterima atau tidak terhadap judul-judul yang diajukan oleh mahasiswa masih dilakukan secara manual yaitu dengan mengecek satu-persatu sehingga membutuhkan waktu yang lama dan kurang efektif. Sistem pendeteksian kemiripan judul skripsi dengan menggunakan algoritma winnowing dirancang untuk memudahkan koordinator tugas akhir atau Ketua Program Studi dalam menentukan persentase kemiripan dengan judul yang telah ada. Sistem akan meminta sebuah masukkan berupa judul yang akan di cek kemiripannya dan menampilkan hasilnya kepada user. Dari 117 judul skripsi yang telah ada, terdapat 11 judul yang sama terhadap judul yang dimasukkan dengan tingkat kemiripan lebih besar sama dengan 20 persen. Dengan adanya sistem ini diharapkan proses-proses tersebut menjadi lebih mudah, cepat dan efektif.
\end{abstract}

Keywords: algoritma winnowing, deteksi kemiripan, plagiarisme, judul skripsi

\section{PENDAHULUAN}

Skripsi atau Tugas Akhir merupakan salah satu mata kuliah wajib yang harus diselesaikan oleh setiap mahasiswa. Skripsi merupakan persyaratan yang harus ditempuh untuk mendapatkan status sarjana (S1) di setiap Perguruan Tinggi Negeri (PTN) maupun Perguruan Tinggi Swasta (PTS) yang ada di Indonesia. Banyak mahasiswa yang mengalami kegagalan dalam kuliah hanya lantaran karena bingung dan tidak sanggup membuat skripsi hingga selesai. Kegagalan ini tentu saja membuat kecewa banyak orang, mulai dari diri sendiri dan orang tua.

Ketidakmampuan mahasiswa dalam memilih judul skripsi memang banyak sekali faktornya, salah satu diantaranya adalah karena tidak tahu atau bingung dalam menentukan tema. Ada beberapa mahasiswa yang sudah memiliki ide untuk judul skripsi mereka, akan tetapi belum dapat menentukan apakah judul tersebut akan diterima atau ditolak. Hal ini terjadi karena tidak adanya sistem yang menyediakan informasi mengenai daftar judul-judul yang telah diambil dan tidak adanya sistem yang mampu mengecek seberapa besar persentase kemiripan terhadap judul-judul yang telah telah ada.

Dalam menentukan diterima atau tidaknya sebuah judul skripsi yang sekarang ini dilakukan adalah dengan mengecek atau membandingkan judul tersebut dengan daftar judul-judul yang telah ada secara manual yaitu dengan melihat satu-persatu. Tentu saja hal ini akan membutuhkan waktu yang cukup lama belum lagi jika pengaju judul skripsi berjumlah banyak, tidak menutup kemungkinan waktu yang dibutuhkan juga akan semakin lama. Di samping itu, pengelolaan daftar judul-judul yang telah ada juga masih manual sehingga tidak menutup kemungkinan data akan hilang dan sulit dalam mendistribusikan informasi tersebut kepada mahasiswa.

Oleh karena itu, diperlukan suatu sistem yang mampu mendeteksi persentase kemiripan judul secara cepat dan tepat dan mampu menyediakan informasi tersebut kepada seluruh mahasiswa. Dengan sistem ini, Koordinator Tugas Akhir atau Ketua Program Studi nantinya hanya memasukkan judul yang akan diajukan ke formulir yang telah disediakan, kemudian sistem akan mengecek secara otomatis dan menampilkan hasilnya. Hasil tersebut bisa dijadikan sebagai pertimbangan dalam menentukan apakah diterima atau ditolak judul tersebut.

\section{LANDASAN TEORI}

\section{A. Algoritma winnowing}

Winnowing adalah algoritma yang digunakan untuk melakukan proses document fingerprinting. Document fingerprinting merupakan metode yang digunakan untuk mendeteksi keakuratan salinan antar dokumen atau hanya sebagian teks saja. Prinsip kerja dari metode document fingerprinting ini adalah dengan menggunakan teknik hashing. Teknik hashing adalah sebuah fungsi yang mengkonversi setiap string menjadi bilangan. Proses ini ditujukan agar dapat mengidentifikasi kemiripan, termasuk bagian-bagian kecil yang mirip dalam dokumen yang berjumlah banyak. [2].

Input dari proses document fingerprinting adalah file teks. Kemudian outputnya akan berupa sekumpulan nilai hash yang disebut fingerprint. Fingerprint inilah yang akan dijadikan dasar pembanding antar file-file teks 
yang telah dimasukkan. Fungsi yang digunakan untuk mencari nilai hash dalam winnowing adalah rolling hash.

Salah satu prasyarat dari algoritma deteksi penjiplakan adalah whitespace insensitivity, Winnowing telah memenuhi prasyarat tersebut dengan cara membuang seluruh karakter-karakter yang tidak relevan misal: tanda baca, spasi dan juga karakter lain, sehingga nantinya hanya karakter-karakter yang berupa huruf atau angka yang akan diproses lebih lanjut. Winnowing adalah algoritma untuk proses document fingerprinting, yang meliputi beberapa tahap, yaitu: pembersihan teks, pembuatan rangkaian gram, pencarian nilai hash, dan pemilihan nilai hash untuk dijadikan fingerprint.[2].

\section{B. Langkah-langkah algoritma Winnowing}

1. Tahap pertama adalah pembuangan karakter yang tidak relevan misalnya tanda baca, spasi dan lainlain. Misalnya "Nama saya Amin Munthoha" akan diubah menjadi namasayaaminmunthoha.

2. Tahap kedua adalah pembentukan rangkaian gram dari teks yang telah dibersihkan dengan ukuran $k$. Misalnya ukuran $k=4$. nama amas masa asay saya ayaa yaam aami amin minm inmu nmun munth unth ntho thoh hoha.

3. Pada tahap ketiga dilakukan perhitungan nilai-nilai hash dari setiap gram menggunakan rolling hash. 912584559085855794938629979383018482 92059033936294049816942396368945 .

4. Lalu dibentuk window dari nilai-nalai hash dengan ukuran $w=4$. $\{9125845590858557\},\{84559085$ $85579493\},\{9085855794938629\},\{85579493$ $86299793\},\{9493862997938301\},\left\{\begin{array}{l}86299793 \\ 8301\end{array}\right.$ $83018482\},\{9793830184829205\},\left\{\begin{array}{lll}83018482\end{array}\right.$

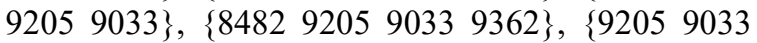
$93629404\},\{9033936294049816\},\{93629404$ $98169423\},\{9404981694239636\},\{88169423$ $96368945\}$.

5. Tahap terakhir memilih nilai terkecil dari setiap window untuk dijadikan fingerprint $[8455,1][8557$, 3] $[8301,7][8482,8][9033,10][9362,11][9404$, 12] $[8945,16]$

\section{Rolling hash}

Hashing adalah suatu cara untuk mentransformasi sebuah string menjadi suatu nilai yang unik dengan panjang tertentu (fixed-length) yang berfungsi sebagai penanda string tersebut. Fungsi untuk menghasilkan nilai ini disebut fungsi hash, sedangkan nilai yang dihasilkan disebut nilai hash.

Fungsi yang digunakan untuk menghasilkan nilai hash dari rangkaian gram dalam algoritma Winnowing adalah rolling hash. Fungsi hash $H_{(c 1 . . c k)}$ didefinisikan sebagai berikut .[2]:

$$
H_{(c k)}=c_{1} * b^{(k-1)}+c_{2} * b^{(k-2)}+\cdots \cdot+c_{k} * b^{(k-k)}
$$

Keterangan :
$\mathrm{C}:$ nilai ascii karakter
$\mathrm{b}$ : basis (bilangan prima)
$\mathrm{k}$ : banyak karakter

\section{Dice similarity coefficient}

Dice Similarity Coefficient digunakan untuk menghitung kemiripan (similarity) dari kumpulan katakata yang telah dihitung nilai hash nya. Berikut ini persamaan rumus Dice Similarity Coefficient .[5]:

$$
\mathrm{S}=\frac{2 C}{A+B}
$$

Keterangan :

$\mathrm{S}:$ Kemiripan (similarity)

A :Jumlah dari kumpulan k-grams dari dokumen A

$\mathrm{B}$ :Jumlah dari kumpulan $k$-grams dari dokumen B

$\mathrm{C}$ :Jumlah k-grams yang sama dari teks yang dibandingkan.

\section{A. Skema Sistem}

\section{HASIL DAN PEMBAHASAN}

Berikut ini penjelasan mengenai skema sistem yang akan dibuat:

a. Start merupakan proses awal menjalankan sistem.

b. Masukkan Judul. Program meminta masukkan berupa judul yang akan di cek kemiripannya.

c. Preprocessing. Proses ini dilakukan oleh sistem dengan tujuan untuk membersihkan teks yang tidak relevan seperti tanda baca, simbol-simbol dan lain sebagainya.

d. Proses Winnowing. Proses ini memiliki beberapa subproses yaitu membuat rangkaian gram dengan panjang $k$, mencari nilai hash dari masing-masing rangkaian gram, membentuk window dengan ukuran $w$, mencari fingerprint dari tiap-tiap window, mencari nilai hash yang sama berdasarkan fingerprint yang ada

e. Proses Perhitungan Similaritas. Menghitung persentase kemiripan dengan menggunakan persamaan rumus Dice Similarity Coefficient.

f. Kesimpulan. Menampilkan hasil dari perhitungan dan selesai 


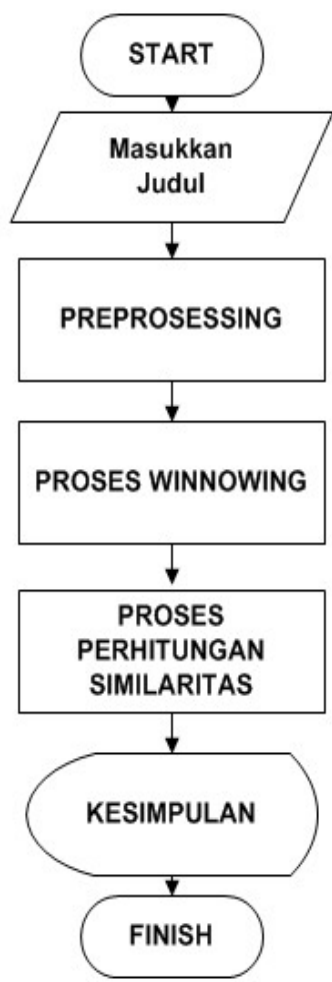

Gbr 1. Skema Sistem

\section{B. Implementasi Algoritma Winnowing}

Algoritma winnowing memiliki beberapa langkah yang digunakan yaitu masukkan judul, pembersihan teks, pembuatan rangkaian gram, mencari nilai hash dari tiap rangkaian gram, membentuk window dari rangkaian nilai hash, mencari fingerprint, mencari nilai hash yang sama, dan menentukan persentase kemiripan judul menggunakan rumus Dice Similarity Coefficient.

a. Masukkan dua buah judul yang akan dibandingkan

TABEL I

JUDUL YANG DIBANDINGKAN

\begin{tabular}{|l|l|}
\hline Judul 1 & Judul 2 \\
\hline Sistem Pendukung & Sistem Pendukung Keputusan \\
Keputusan Penentuan & Penentuan Jaringan \\
Pemilihan Jurusan Di & Menggunakan Smart Dan \\
Unimal Dengan & SAW (Simple Additive \\
Menggunakan Metode & Weighting) \\
Tsukamoto & \\
\hline
\end{tabular}

b. Pembersihan teks pada masing-masing judul
TABEL II

PEMBERSIHAN TEKS PADA MASING-MASING JUDUL

\begin{tabular}{|l|l|}
\hline Judul 1 & Judul 2 \\
\hline $\begin{array}{l}\text { Sistempendukungkeput } \\
\text { usanpenentuanpemiliha } \\
\text { njurusandiunimaldenga } \\
\text { nmenggunakanmetodet } \\
\text { sukamoto }\end{array}$ & $\begin{array}{l}\text { Sistempendukungkeputus } \\
\text { anpenentuanjaringanmeng } \\
\text { gunakansmartdansawsimp } \\
\text { leadditiveweighting }\end{array}$ \\
\hline
\end{tabular}

c. Pembuatan rangkaian gram dengan panjang $k=7$

TABEL III

PEMBUATAN RANGKAIAN GRAM

\begin{tabular}{l|l}
\hline Judul 1 & Judul 2 \\
\hline sistemp istempe stempen & sistemp istempe stempen \\
tempend empendu mpenduk & tempend empendu \\
penduku endukun ndukung & mpenduk penduku \\
dukungk ukungke kungkep & endukun ndukung \\
ungkepu ngkeput gkeputu & dukungk ukungke \\
keputus eputusa putusan & kungkep ungkepu ngkeput \\
utusanp tusanpe usanpen & gkeputu keputus eputusa \\
sanpene anpenen npenent & putusan utusanp tusanpe \\
penentu enentua nentuan & usanpen sanpene anpenen \\
entuanp ntuanpe tuanpem & npenent penentu enentua \\
uanpemi anpemil npemili & nentuan entuanj ntuanja \\
pemilih emiliha milihan & tuanjar uanjari anjarin \\
ilihanj lihanju ihanjur hanjuru & njaring jaringa aringan \\
anjurus njurusa jurusan & ringanm inganme \\
urusand rusandi usandiu & nganmen ganmeng \\
sandiun andiuni ndiunim & anmengg nmenggu \\
diunima iunimal unimald & menggun engguna \\
nimalde imalden maldeng & nggunak ggunaka gunakan \\
aldenga ldengan denganm & unakans nakansm \\
enganme nganmen ganmeng & akansma kansmar ansmart \\
anmengg nmenggu menggun & nsmartd smartda martdan \\
engguna nggunak ggunaka & artdans rtdansa tdansaw \\
gunakan unakanm nakanme & dansaws ansawsi nsawsim \\
akanmet kanmeto anmetod \\
nmetode metodet etodets & sawsimp awsimpl \\
todetsu odetsuk detsuka & wsimple simplea implead \\
etsukam tsukamo sukamot & mpleadd pleaddi leaddit \\
ukamoto & eadditi additiv dditive \\
ditivew itivewe tivewei \\
iveweig veweigh eweight \\
weighti eightin ighting \\
\hline
\end{tabular}

d. Mencari nilai hash dari masing-masing gram dengan menggunakan fungsi rolling hash

$H_{(c)}=C_{1} \times b^{(k-1)}+C_{2} \times b^{(k-2)}+\ldots+C_{k} \times b^{(k-k)}$

sebagai contoh mencari nilai hash dari gram sistemp

1. Nilai ascii dari tiap-tiap karakter

Ascii $\mathrm{s}=115$, ascii $\mathrm{i}=105$, ascii $\mathrm{t}=116$, ascii $\mathrm{e}=$ 101 , ascii $\mathrm{m}=109$, ascii $\mathrm{p}=112$

2. Nilai hash dari sistemp 


$$
\begin{aligned}
\mathrm{H}= & \left(115 \times 11^{(7-1)}\right)+\left(105 \times 11^{(7-2)}\right)+(115 \times \\
& \left.11^{(7-3)}\right)+\left(116 \times 11^{(7-4)}\right)+\left(101 \times 11^{(7-5)}\right) \\
& +\left(109 \times 11^{(7-6)}\right)+\left(112 \times 11^{(7-7)}\right) \\
\mathrm{H}= & (203729515)+(16910355)+(1683715)+ \\
& (154396)+(12221)+(1199)+(112) \\
\mathrm{H}= & 222491513
\end{aligned}
$$

TABEL IV

NILAI HASH MASING-MASING GRAM

\begin{tabular}{|l|l|}
\hline Judul 1 & Judul 2 \\
\hline 222491513206382079 & 222491513206382079 \\
224050024223525699 & 224050024223525699 \\
198270970212776506 & 198270970212776506 \\
216440044198277442 & 216440044198277442 \\
212847694197735931 & 212847694197735931 \\
226378242210161767 & 226378242210161767 \\
226652257213175936 & 226652257213175936 \\
201346603207634135 & 201346603207634135 \\
198848285219126974 & 198848285219126974 \\
227833674226171508 & 227833674226171508 \\
227374862221124576 & 227374862221124576 \\
191345781214548120 & 191345781214548120 \\
216440627198283842 & 216440627198283842 \\
212918101198510413 & 212918101198510407 \\
215410373225925402 & 215410303225924637 \\
224667691191345702 & 224659276191253139 \\
214547240216430934 & 213529045205230782 \\
198177219211745248 & 191898586220628968 \\
205096195209905307 & 205381255213040960 \\
204344023201631415 & 199861853191301873 \\
191279896213823366 & 214065133211127763 \\
208468326227511560 & 198303851213138197 \\
222628258227373461 & 200931454203067491 \\
221109174191176354 & 226563903212204035 \\
212684416195939863 & 190655672206956919 \\
206621501226683656 & 191398928215132721 \\
213521310205145710 & 222871218210558843 \\
210449958190847996 & 19204574922247749 \\
209072479195182910 & 223187864194554783 \\
198295011213040960 & 191385618214986320 \\
199861853191301873 & 221260822192844485 \\
214065133211127763 & 231033849222399087 \\
198303851213138197 & 205365392212866457 \\
200931454203067491 & 217429493209161387 \\
226563897212203961 & 196160894189565681 \\
190654877206948171 & 194967005195920074 \\
191302684214074038 & 206403815224289115 \\
211225724199381440 & 206668532227201001 \\
224991686214396817 & 199724949228770273 \\
195289103199463142 & 197499764204293236 \\
225890402224282702 & \\
226085168 & \\
\hline
\end{tabular}

e. Membentuk window dengan $w=4$

TABEL V

MEMBENTUK WINDOW

$$
\begin{array}{|l|l|}
\hline \text { Ju } \\
\hline\{2 \\
22 \\
\{2 \\
22 \\
\{2 \\
198 \\
\hline
\end{array}
$$

$\{222491513206382079$ $224050024223525699\}$, $\{206382079224050024$ $223525699198270970\}$, $\{224050024223525699$ $198270970212776506\}$, $\{223525699198270970$ $212776506216440044\}$, $\{198270970212776506$ $216440044198277442\}$, $\{212776506216440044$ $198277442212847694\}$, $\{216440044198277442$ $212847694197735931\}$, $\{198277442212847694$ $197735931226378242\}$, $\{212847694197735931$ $226378242210161767\}$, $\{197735931226378242$ $210161767226652257\}$, $\{226378242210161767$ $226652257213175936\}$, $\{210161767226652257$ $213175936201346603\}$, $\{226652257213175936$ $201346603207634135\}$, $\{213175936201346603$ $207634135198848285\}$, $\{201346603207634135$ $198848285219126974\}$, $\{207634135198848285$ $219126974227833674\}$, $\{198848285219126974$ $227833674226171508\}$, $\{219126974227833674$ $226171508227374862\}$, $\{227833674226171508$ $227374862221124576\}$, $\{226171508227374862$ $221124576191345781\}$, $\{227374862221124576$ $191345781214548120\}$, $\{221124576191345781$ $214548120216440627\}$, $\{191345781214548120$ $216440627198283842\}$, $\{214548120216440627$ $198283842212918101\}$, $\{216440627198283842$ $212918101198510413\}$, $\{198283842212918101$ $198510413215410373\}$,
Judul 2

$\{222491513206382079$ $224050024223525699\}$, \{206382079 224050024 $223525699198270970\}$, $\{224050024223525699$ $198270970212776506\}$, $\{223525699198270970$ $212776506216440044\}$, $\{198270970212776506$ $216440044198277442\}$, $\{212776506216440044$ $198277442212847694\}$, $\{216440044198277442$ $212847694197735931\}$, $\{198277442212847694$ $197735931226378242\}$, $\{212847694197735931$ $226378242210161767\}$, $\{197735931226378242$ $210161767226652257\}$, $\{226378242210161767$ $226652257213175936\}$, $\{210161767226652257$ $213175936201346603\}$, $\{226652257213175936$ $201346603207634135\}$, $\{213175936201346603$ $207634135198848285\}$, $\{201346603207634135$ $198848285219126974\}$, $\{207634135198848285$ $219126974227833674\}$, $\{198848285219126974$ $227833674226171508\}$, $\{219126974227833674$ $226171508227374862\}$, $\{227833674226171508$ $227374862221124576\}$, $\{226171508227374862$ $221124576191345781\}$, $\{227374862221124576$ $191345781214548120\}$, $\{221124576191345781$ $214548120216440627\}$, $\{191345781214548120$ $216440627198283842\}$, $\{214548120216440627$ $198283842212918101\}$, $\{216440627198283842$ $212918101198510407\}$, $\{198283842212918101$ $198510407215410303\}$, 


\begin{tabular}{|c|c|}
\hline$\{212918101198510413$ & $\{212918101198510407$ \\
\hline 215410373225925402$\}$, & $215410303225924637\}$ \\
\hline$\{198510413215410373$ & $\{198510407215410303$ \\
\hline 225925402224667691$\}$, & $225924637224659276\}$ \\
\hline$\{215410373225925402$ & $\{215410303225924637$ \\
\hline 224667691191345702$\}$, & $224659276191253139\}$ \\
\hline$\{225925402224667691\}$ & $\{225924637224659276$ \\
\hline 191345702214547240$\}$, & $191253139213529045\}$ \\
\hline$\{224667691191345702$ & $\{224659276191253139$ \\
\hline 214547240216430934$\}$, & $213529045205230782\}$ \\
\hline$\{191345702214547240$ & $\{191253139213529045$ \\
\hline 216430934198177219$\}$, & $205230782191898586\}$, \\
\hline$\{214547240216430934$ & $\{213529045205230782$ \\
\hline 198177219211745248$\}$, & $191898586220628968\}$, \\
\hline$\{216430934198177219$ & $\{205230782191898586$ \\
\hline 211745248205096195$\},$ & $220628968205381255\}$, \\
\hline $\begin{array}{r}\{198177219211745248 \\
205096195209905307\} .\end{array}$ & $\begin{array}{l}\{191898586220628968 \\
205381255213040960\} .\end{array}$ \\
\hline$\{211745248205096195$ & $\{220628968205381255$ \\
\hline 209905307204344023$\}$, & $213040960199861853\}$ \\
\hline$\{205096195209905307$ & $\{205381255213040960$ \\
\hline 204344023201631415$\}$, & $199861853191301873\}$, \\
\hline$\{209905307204344023$ & $\{213040960199861853$ \\
\hline 201631415191279896$\}$, & $191301873214065133\}$ \\
\hline$\{204344023201631415$ & $\{199861853191301873$ \\
\hline 191279896213823366$\}$, & $214065133211127763\}$ \\
\hline$\{201631415191279896$ & $\{191301873214065133$ \\
\hline 213823366208468326$\}$, & $211127763198303851\}$, \\
\hline$\{191279896213823366$ & $\{214065133211127763$ \\
\hline 208468326227511560$\}$, & $198303851213138197\}$, \\
\hline$\{213823366208468326$ & $\{211127763198303851$ \\
\hline $\begin{array}{l}227511560222628258\}, \\
\{208468326227511560\end{array}$ & $\begin{array}{l}213138197200931454\} \\
\{198303851213138197\end{array}$ \\
\hline 222628258227373461$\}$, & $200931454203067491\}$ \\
\hline$\{227511560222628258$ & $\{213138197200931454$ \\
\hline $\begin{array}{l}227373461221109174\}, \\
\{222628258227373461\end{array}$ & $203067491226563903\}$, \\
\hline $\begin{array}{l}28258227 \\
1741911\end{array}$ & $\begin{array}{l}\{20093145420306 / 491 \\
226563903212204035\}\end{array}$ \\
\hline $\begin{array}{l}221109174191176354\}, \\
\{227373461221109174\end{array}$ & $\{203067491226563903\}$ \\
\hline 191176354212684416$\}$, & $212204035190655672\}$ \\
\hline$\{221109174191176354$ & $\{2265 t\}$ \\
\hline 212684416195939863$\}$, & $190655672206956919\}$ \\
\hline$\{191176354212684416$ & $\{212204035190655672$ \\
\hline 195939863206621501$\}$, & $206956919191398928\}$, \\
\hline$\{212684416195939863$ & $\{190655672206956919$ \\
\hline 206621501226683656$\}$, & $191398928215132721\}$, \\
\hline & \\
\hline 226683656213521310$\}$, & $215132721222871218\}$, \\
\hline$\{206621501226683656$ & $\begin{array}{l}\{191398928215132721 \\
222871218210558843\}\end{array}$ \\
\hline$\{226683656213521310\}$ & $\{215132721222871218$ \\
\hline 205145710210449958$\}$, & $210558843192045749\}$ \\
\hline$\{213521310205145710$ & $\{222871218210558843$ \\
\hline 210449958190847996$\}$, & $192045749222247749\}$ \\
\hline$\{205145\}$ & $\{210558843192045749$ \\
\hline 190847996209072479$\}$, & $222247749223187864\}$ \\
\hline
\end{tabular}

$\{210449958190847996$ $209072479195182910\}$, $\{190847996209072479$ $195182910198295011\}$, $\{209072479195182910$ $198295011213040960\}$, $\{195182910198295011$ $213040960199861853\}$, $\{198295011213040960$ $199861853191301873\}$, $\{213040960199861853$ $191301873214065133\}$, $\{199861853191301873$ $214065133211127763\}$, $\{191301873214065133$ $211127763198303851\}$, $\{214065133211127763$ $198303851213138197\}$, $\{211127763198303851$ $213138197200931454\}$, $\{198303851213138197$ $200931454203067491\}$, $\{213138197200931454$ $203067491226563897\}$, $\{200931454203067491$ $226563897212203961\}$, $\{203067491226563897$ $212203961190654877\}$, $\{226563897212203961$ $190654877206948171\}$, $\{212203961190654877$ $206948171191302684\}$, $\{190654877206948171$ $191302684214074038\}$, $\{206948171191302684$ $214074038211225724\}$, $\{191302684214074038$ $211225724199381440\}$, $\{214074038211225724$ $199381440224991686\}$, $\{211225724199381440$ $224991686214396817\}$, $\{199381440224991686$ $214396817195289103\}$, $\{224991686214396817$ $195289103199463142\}$, $\{214396817195289103$ $199463142225890402\}$, $\{195289103199463142$ $225890402224282702\}$, $\{199463142225890402$ $224282702226085168\}$,

f. Mencari Fingerprint dari masing-masing window (nilai terkecil tiap window) TABEL VI
$\{192045749222247749$ $\{222247749223187864$ $194554783191385618\}$, $\{223187864194554783$ $191385618214986320\}$, $\{194554783191385618$ $214986320221260822\}$, $\{191385618214986320$ $221260822192844485\}$, $\{214986320221260822$ $192844485231033849\}$, $\{221260822192844485$ $231033849222399087\}$, $\{192844485231033849$ $222399087205365392\}$, $\{231033849222399087$ $205365392212866457\}$, $\{222399087205365392$ $212866457217429493\}$, $\{205365392212866457$ $217429493209161387\}$, $\{212866457217429493$ $209161387196160894\}$, $\{217429493209161387$ $196160894189565681\}$, $\{209161387196160894$ $189565681194967005\}$, $\{196160894189565681$ $194967005195920074\}$, $\{189565681194967005$ $195920074206403815\}$, $\{194967005195920074$ $206403815224289115\}$, $\{195920074206403815$ $224289115206668532\}$, $\{206403815224289115$ $206668532227201001\}$, $\{224289115206668532$ $227201001199724949\}$, $\{206668532227201001$ $199724949228770273\}$, $\{227201001199724949$ $228770273197499764\}$, $\{199724949228770273$ $197499764204293236\}$,

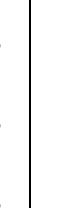

$223187864194554783\}$, 


\section{MENCARI FINGERPRINT}

\begin{tabular}{|l|l|}
\hline Judul 1 & Judul 2 \\
\hline 206382079198270970 & 206382079198270970 \\
198277442197735931 & 198277442197735931 \\
210161767201346603 & 210161767201346603 \\
198848285219126974 & 198848285219126974 \\
221124576191345781 & 221124576191345781 \\
198283842198510413 & 198283842198510407 \\
191345702198177219 & 191253139191898586 \\
204344023201631415 & 199861853191301873 \\
191279896208468326 & 198303851200931454 \\
221109174191176354 & 190655672191398928 \\
195939863205145710 & 192045749191385618 \\
190847996195182910 & 192844485205365392 \\
191301873198303851 & 196160894189565681 \\
200931454190654877 & 194967005195920074 \\
191302684199381440 & 206403815199724949 \\
195289103199463142 & 197499764 \\
\hline
\end{tabular}

g. Mencari nilai hash yang sama dari masing-masing fingerprint

TABEL VII

MENCARI NILAI HASH

\begin{tabular}{|l|l|}
\hline Judul 1 & Judul 2 \\
\hline 206382079198270970 & 206382079198270970 \\
198277442197735931 & 198277442197735931 \\
210161767201346603 & 210161767201346603 \\
198848285219126974 & 198848285219126974 \\
221124576191345781 & 221124576191345781 \\
198283842191301873 & 198283842191301873 \\
198303851200931454 & 198303851200931454 \\
\hline
\end{tabular}

h. Menentukan persentase kemiripan judul menggunakan rumus Dice Similarity Coefficient

$\mathrm{S}=\frac{2 C}{(A+B)}$

Dari hasil perhitungan diatas, diketahui:

$\mathrm{C}=14$

$\mathrm{A}=32$

$\mathrm{B}=31$

Maka

$\begin{array}{ll}\mathrm{S} & =\frac{2 \times 1}{(3+3)} \\ \mathrm{S} & =44,4\end{array}$

\section{Implementasi Sistem}

\section{Form Utama}

Berikut ini tampilan dari form utama yang ada pada halaman admin atau mahasiswa. Form ini hanya menampilkan informasi mengenai program.

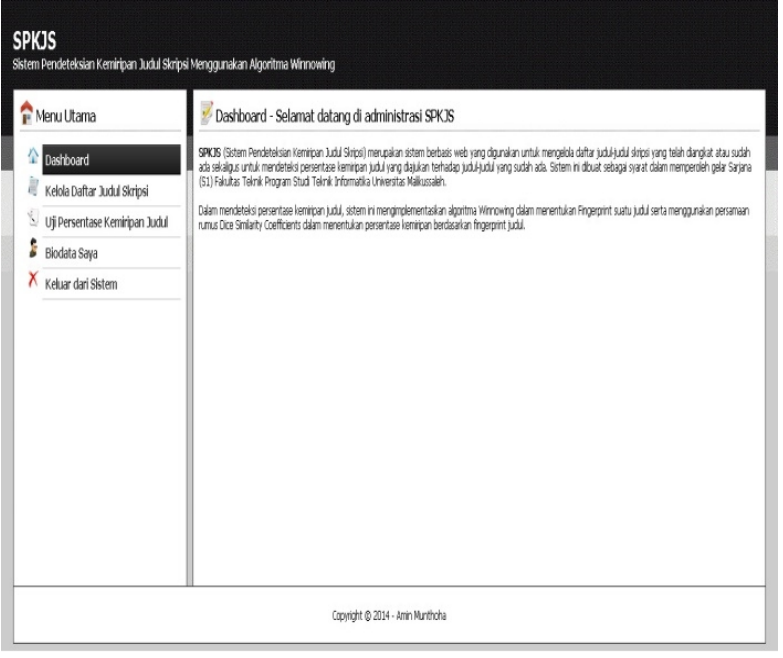

Gbr 2. Form Utama

\section{Form Kelola Data Judul Skripsi}

Form kelola data judul skripsi digunakan untuk menampilkan daftar judul-judul skripsi yang telah ada. Data yang ditampilkan antara lain nim, nama mahasiswa, tanggal input, tahun lulus, judul skripsi dan tempat studi kasus. Berikut ini tampilannya.

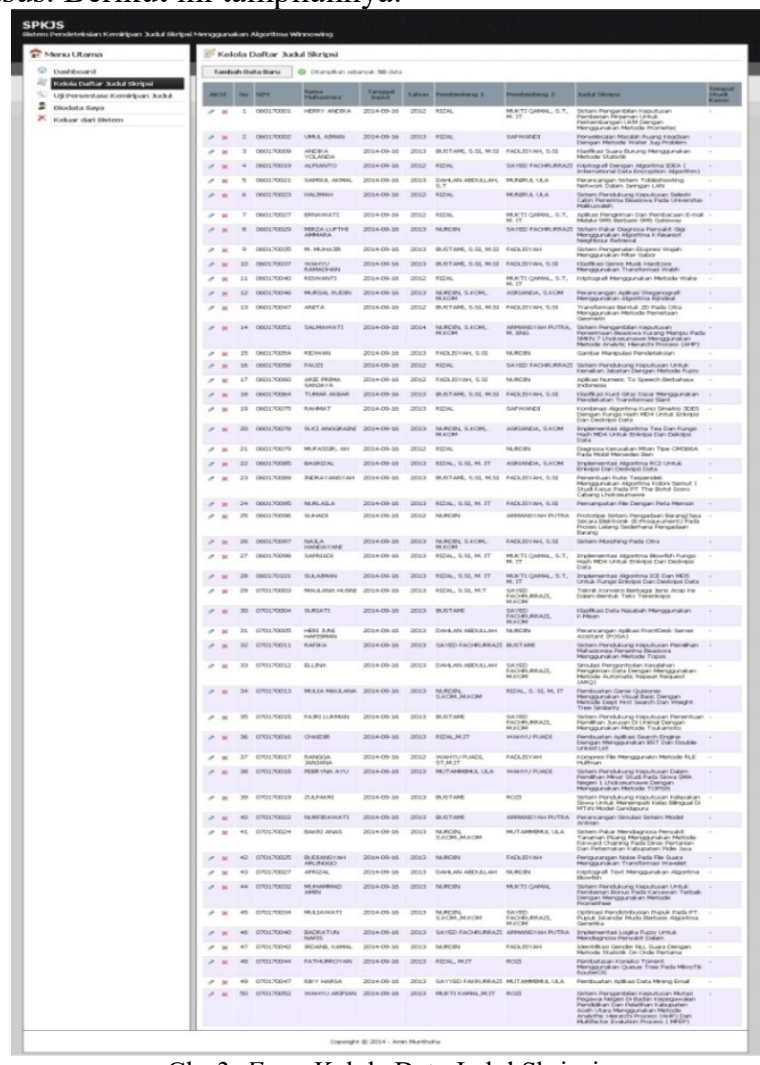

Gbr 3. Form Kelola Data Judul Skripsi

\section{Form Tambah Data Judul Skripsi}

Form tambah data judul skripsi digunakan untuk menambah atau mengubah data-data judul skripsi yang telah ada. Berikut ini tampilannya. 


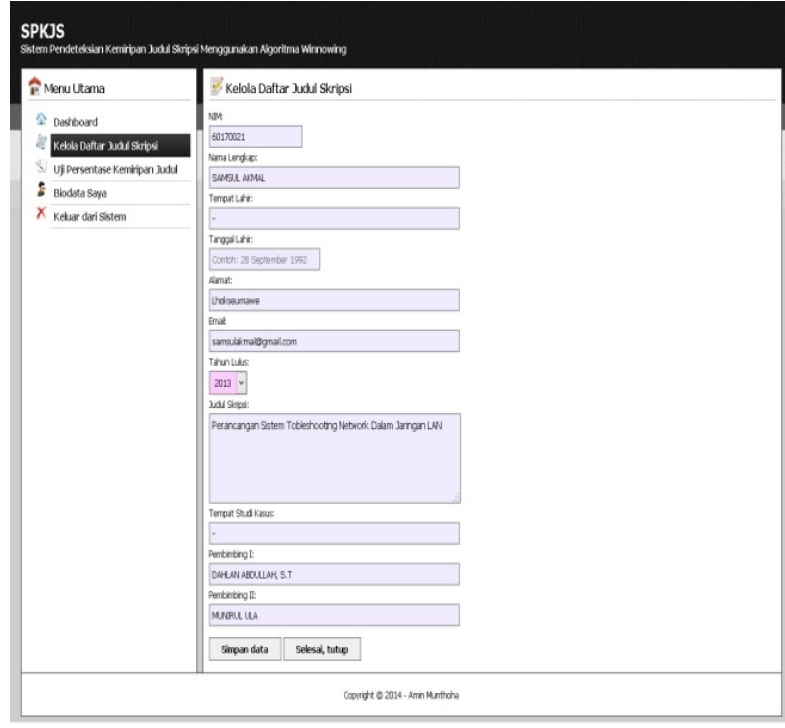

Gbr 4. Form Tambah Data Judul Skripsi

\section{Form Uji Persentase Kemiripan Judul}

Form uji persentase kemiripan judul skripsi digunakan untuk memasukkan judul yang ingin diuji persentase tingkat kemiripan terhadap judul-judul yang telah ada. User cukup memasukkan judul ke dalam kolom isian yang telah disediakan, kemudian klik tombol Uji kemiripan judul. Sistem akan menampilkan daftar judul beserta persentase kemiripannya. Berikut ini tampilannya.

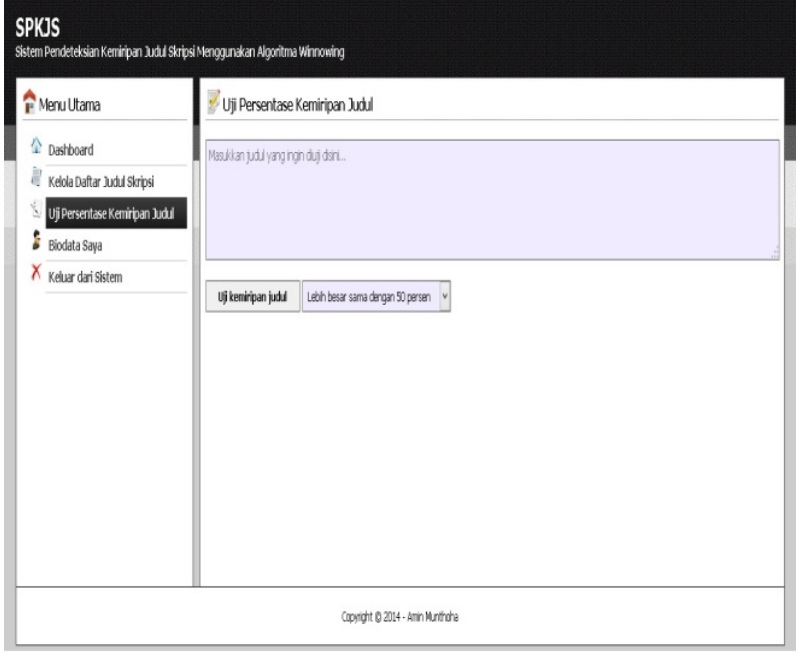

Gbr 5. Form Uji Kemiripan Judul Skripsi

\section{Form Hasil Pengujian}

Form ini menampilkan daftar judul hasil dari perhitungan yang telah dilakukan. Data yang ditampilkan meliputi Persentase, nim, nama mahasiswa, tahun selesai dan judul skripsi. Berikut ini tampilannya.

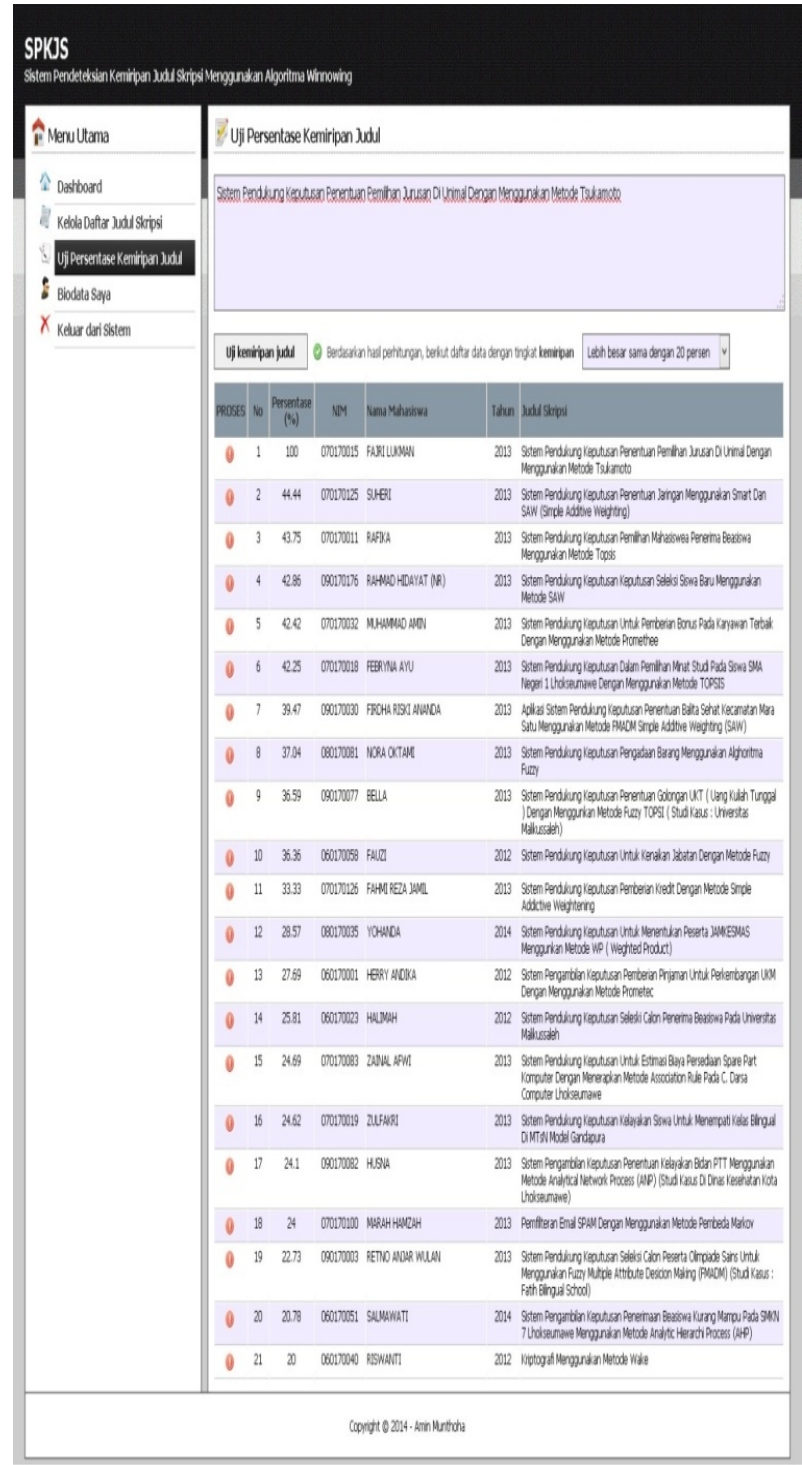

Gbr 6. Form Hasil Pengujian

\section{Form Detail Perhitungan}

Form detail perhitungan ini menampilkan informasi rincian tentang proses-proses perhitungan yang dilakukan dengan menggunakan algoritma winnowing. Berikut ini tampilannya. 


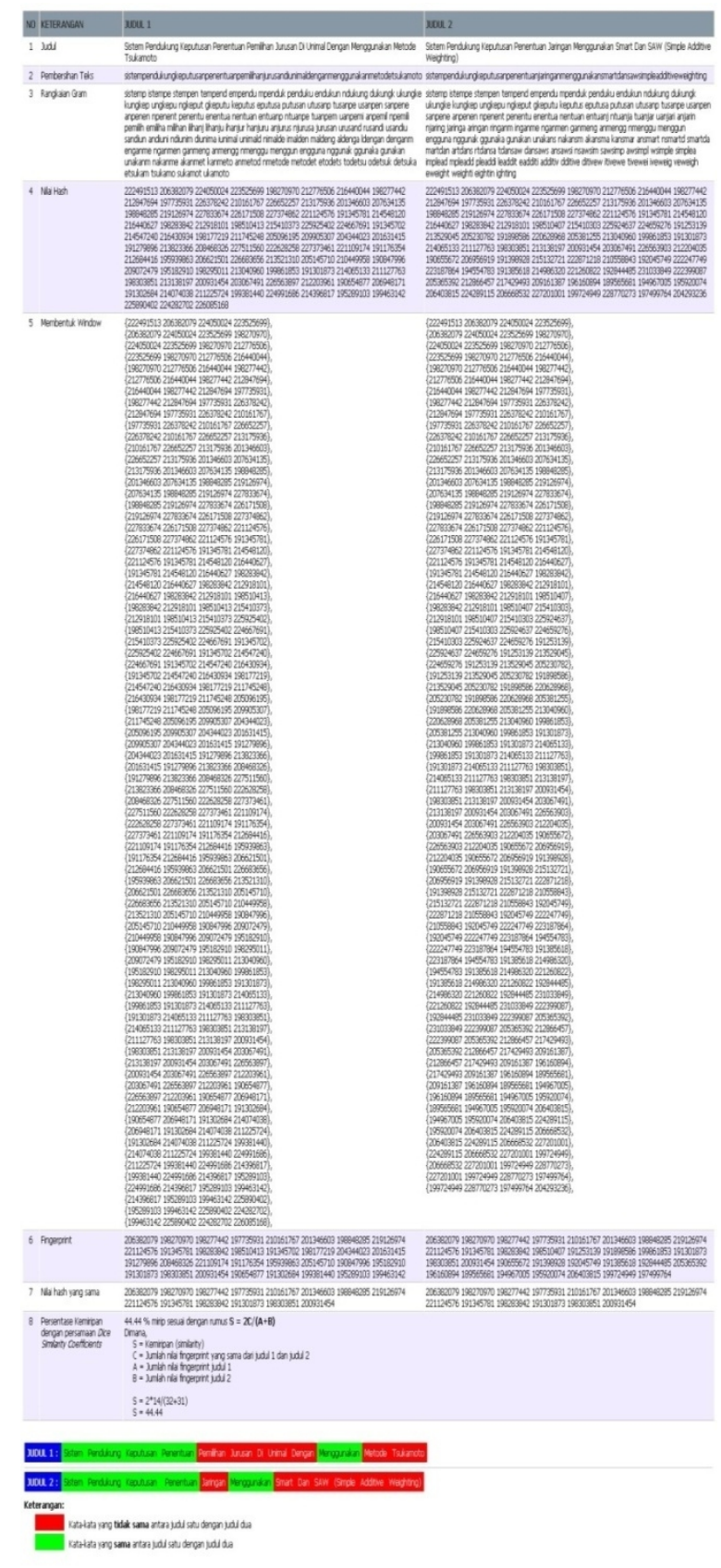

Gbr 7. Form Detail Perhitungan

\section{KESIMPULAN}

1. Proses pengelolaan judul skripsi yang sebelumnya mengalami beberapa kendala baik dalam pengelolaan maupun pendistribusian informasi ke mahasiswa, kini menjadi lebih baik dan lebih cepat.

2. Untuk mendapatkan informasi mengenai judul yang telah diambil, mahasiswa bisa langsung mengaksesnya secara online.
3. Dari 117 judul skripsi yang telah ada, terdapat 11 judul yang sama terhadap judul yang dimasukkan dengan tingkat kemiripan lebih besar sama dengan 20 persen.

4. Waktu lamanya proses tergantung dari kecepatan koneksi internet yang digunakan. Dalam pengujian yang telah dilakukan (offline) terhadap 117 judul skripsi yang telah ada, dibutuhkan waktu sekitar 2.2333 detik

5. Proses penentuan persentase kemiripan judul skripsi menjadi lebih cepat dan akurat sesuai dengan algoritma yang digunakan. Hal ini tentu membantu koordinator tugas akhir atau Ketua Program Studi dalam menentukan di terima atau tidaknya judul yang diajukan oleh mahasiswa. Sebelum mengajukan ke koordinator tugas akhir, mahasiswa juga dapat melakukan pengecekan sendiri terhadap judul skripsi yang telah direncanakan apakah sudah ada ataukah belum, sehingga lebih transparan bilamana judul tersebut ditolak.

\section{REFERENCE}

[1] Christian., 2013. Perancangan Sistem Deteksi Plagiarisme Dokumen Teks Menggunakan Algoritma Damerau Levenshtein Distance. Jurnal Mahasiswa PTIIK UB Vol.2 No.1, 2013.

[2] Pratama Riyan Mudafiq., 2011. Aplikasi Pendeteksi Duplikasi Dokumen Teks Bahasa Indonesia Menggunakan Algoritma Winnowing Dengan Metode K-Gram dan Synonym Recognition. Jurnal Tugas Akhir Jurusan Teknik Informatika Universitas Muhammadiyah Malang.

[3] Ramadhan Arief., 2006. Student Guide Series- Pemrograman Web Database dengan PHP dan MySQL. PT Elex Media Komputindo, Jakarta.

[4] Stein, Benno, Sven Meyer zu Eissen. 2006. Selected Papers from the 29th Annual Conference of the German Classification Society (GfKl) Magdeburg: Near Similarity Search and Plagiarism Analysis. ISBN 1431-8814, pp. 430437, c Springer 2006

[5] Surahman Mirza Ade., 2013. Perancangan Sistem Penentuan Similarity Kode Program pada Bahasa C dan Pascal dengan Menggunakan Algoritma Rabin-Karp. Jurnal Tugas Akhir Teknik Informatika Universitas Tanjungpura. 